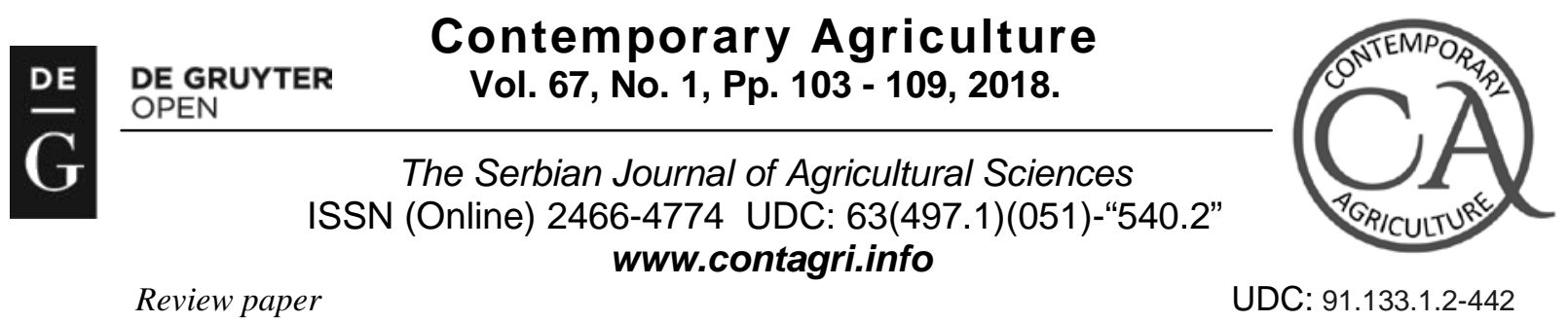

Review paper

DOI: $10.2478 /$ contagri-2018-0015

\title{
SPECIFICS OF ORGANIC FOOD MARKETS’ DEMAND
}

\author{
Marija NIKOLIĆ ${ }^{1}$
}

\begin{abstract}
Summary: Organic food market in Serbia is characterized by underdeveloped supply and limited demand. Demand of organically produced food has certain specifics. Paper analyzes research results of domestic and foreign authors aiming to identify key characteristics and to carry out a systematization of the factors that determine demand and consumption of organic products in Serbian and foreign markets. The aim of the research is to develop demographic profile of organic consumers, and to provide a picture of "typical" organic consumer.

Most authors agree that there is a positive correlation between the level of education and consumption of organic products. Studies conducted in Serbia suggest that concern for health is one of the most important factors of buying organic products, while foreign customers, in addition, are also motivated by environmental and animal welfare attributes, and with desire to consume "local" food. In both groups of consumers sensory characteristics of the product were recognized as the key factors for the consumption of organic products. Price is one of the relevant factors that limit the purchase of these products. Significant attention was paid to marketing channels. Since domestic organic producers are underdeveloped and unadjusted to customers' requirements, getting familiar with the basic characteristics of buyers of organic food is the starting point for development of adequate marketing concept for growers, processors and retail of this group of products.
\end{abstract}

Key words: demand, characteristics, consumers, organic food market

\section{INTRODUCTION}

The interest in organic food has been intensified over the last two decades with enhancing supply, but also with increasing demand for these products, motivated by the desire of consumers for a better and healthier diet (Aertsens et al, 2009). The tendencies in supply and demand of organic food have not been harmonized, especially in less developed markets, and research related to the consumption of organic products has been focused on examining the socio-demographic characteristics of consumers, marketing channels and factors that motivate or limit the demand for organic food.

The organic food market in Serbia is still underdeveloped (Vehapi and Dolićanin, 2016) and there is a continuous need for supply growth, but also a need to identify groups of consumers that are using or could be motivated to start using these products. In that sense, it is necessary to create an adequate marketing concept for breeders, processors and retailers of this group of products, which is not possible without information on who are consumers and what are their motives for buying organic food. The results of these aspirations are studies presented in this paper aiming to identify the basic characteristics of consumers of organic agrarian products.

\section{MATERIAL AND METHODS}

During the preparation of this paper, studies and papers of domestic and foreign authors involved in the research of the organic food consumers profile were used. Results from 26 studies are presented and analysed in this paper, seven of which written by domestic and 19 by foreign authors. Ten studies were carried out in Europe (three in Croatia, two in Norway and Italy, one in Belgium, and two international research conducted in Germany, UK, Spain and Czech Republic), five in Asia (China, Japan, Taiwan, Thailand and Nepal), three in Oceania (all three in Australia) and one survey was conducted in South America (Brazil). Two types of papers were used as a source of information: first, the papers presenting results of independent research and second, review papers that contained the systematisation of research conducted by other authors. Special attention is paid to the first group (research papers), which are the dominant source of material. All papers presenting research results used survey as a source of information related to consumer attitudes, most often on a sample of several hundred respondents. In addition to these, five review papers, from the second group, were taken into account (two of domestic and three of foreign

\footnotetext{
${ }^{1}$ Marija Nikolić, PhD, Assistant Professor, University of Belgrade, Faculty of Agriculture, Nemanjina 6, Serbia, E-mail: mnikolic@agrif.bg.ac.rs
} 
authors). Although these papers do not present the results of independent research, they contain the systematization of different information and actually enrich the chosen material, which was the basic motive why they were also used as the source for this paper. The papers on which the conducted research was based were selected on the basis of the following criteria: the number of respondents involved in the research, the territorial distribution, the level of cited results achieved by the authors in their work and the period of realization of the research with a special emphasis on the latest results.

The time horizon covered by all the analysed papers is from 2001 to 2017. Papers of foreign authors’ date from 2001 to 2017, and only the surveys on the consumption of organic products in Australia were temporarily limited to the period 2002-2005. Domestic papers cover the period from 2009 til 2016, since before that period the organic markets were not in the focus of the research.

As the main scientific method of research used in this paper were analysis and synthesis of the research results presented in the given sources. In order to examine the differences in the consumption of organic food products in Serbia and other countries, a comparative method has been used.

\section{RESULTS}

In the focus of research on the characteristics of demand for organic foods, there are several key issues, such as: (1) recognition of terms and labels of organic products, (2) motives and limiting factors that determine purchasing and consumption, (3) marketing channel used to deliver organic products to final consumers, (4) socio-demographic characteristics of consumers and (5) the way that consumers experience organic food.

First of all, some research examine the extent to which consumers recognize the term "organic food" and whether they differ it adequately from conventional products (Radman, 2005; Roitner-Schobesberger et al, 2008; Aryal et al, 2009; Vehapi and Dolićanin, 2016; Vlahović and Šojić, 2016). This research issue is characteristic for markets with less developed demand for organic products, including Serbia. The recognition of the term "organic food" on the domestic market is rising. In $201120 \%$ of consumers have never heard of this type of food (Vlahović et al, 2011), while in 2016 only $4.2 \%$ of consumers answered the same way (Vehapi and Dolićanin, 2016). This is on the level of recognition of organic products on the market of neighbouring countries, in which approximately two percent of consumers do not recognize the concept of organic products (Renko and Bošnjak, 2009).

In EU countries, where the consumption of organic food has reached a significant level, more attention is paid to the recognition of labels of organic products (Von Meyer-Höfer et al, 2015). Renko and Bošnjak (2009) state that only $36.6 \%$ of consumers recognized the official sign of the Croatian organic product, which indicate that there is a need for better education of consumers. Similar situation is on domestic market, where nearly $40 \%$ of respondents did not manage to recognize the appropriate label (Vehapi and Dolićanin, 2016).

The second research question, to which a significantly more attention was given, is the research related to the motives of consumers to buy organic products, and factors that limit their consumption. Egoistical motives (i.e. positive health effects) and altruistic motives (i.e. the environmental protection and animal welfare) are listed as the most common motives for organic food purchases, but many consumers express the combination of these two sets of reasons. According to earlier studies (Lockie et al, 2002) there is no reason to assume a direct relationship between levels of environmental, health or other concerns and the consumption of organic food. Later studies, however, show that there is a certain connection between these elements.

The main motive for purchasing organic food is the perception of consumers that these products are healthier than conventional, or that they contain fewer undesirable chemical substances (Table 1). Organoleptic characteristics also represent a significant purchasing factor, since the majority of the consumers consider that these products are good in quality, i.e. better taste and flavour (Aoki, 2015). Aertsens et al. (2009) point that taste, related to the value of hedonism, can play an important role in determining organic food purchases. Renko and Bošnjak (2009) state that almost half of the respondents consider that organic food is healthier, and that most of them are employed and with higher incomes. Zanoli and Naspetti (2001) came up with similar results, suggesting that occasional consumers are primarily motivated with personal satisfaction. This group of consumers also want the products to be good-looking. However, they perceive the appearance of organic products as negative, and as a deterrent from the purchase. The questionable appearance of organically grown products limits their purchase in countries in the region (Radman, 2005). A positive influence on health and higher quality are the primary motives for the purchase of organic products for domestic consumers as well (Vlahović and Šjić, 2016), although sensory characteristics are also important, so one third of respondents expresses the view that organic products have a better flavour and taste (Vlahović et al, 2011).

Consumers in more developed markets pay considerable attention to other motives, such as supporting the local farmers by purchasing locally produced products (Aoki, 2015), environmental friendliness (Lockie et al, 2004), or ethical aspects such as animal welfare (Torjusen et al, 2001; Von Meyer-Höfer et al, 2014). These motives are highly rated by consumers who consume organic products over a longer period of time, while those who have consumed these products for a short time are mainly motivated by curiosity (Chinnici et al, 2002).

The most commonly stated barriers for purchasing is the higher price of organic products compared to the conventional ones, which is emphasized by domestic researchers (Vlahović et al, 2011) as well as foreign ones (Lockie 
et al, 2002; Yin et al, 2010). According to Renko and Bošnjak (2009), more than one third of the respondents (35.2\%) cited high price as a major obstacle to the purchase of organic product. Consumers have shown a willingness to consume more organic products if their price is more reasonable (Radman, 2005; Vlahović and Šjić, 2016). Some authors, however, point out that the high price is not a key reason for the restraining the purchase, or in other words that consumers think that the price of these products is reasonable (Aryal, 2009). The second group of limiting factors relates to poor market supply, inaccessibility of organic products, unsatisfactory supply and similar limitations that make the purchase of these products more difficult to the consumers (in Table 1 presented under the common name "limited offer"). Rakić B. and Rakić M. (2009) state that consumers do not buy these products because they are not satisfied with the offer, they consider it to be extremely seasonally limited, and that most used marketing channels for these products are specialized channels, which prolongs the time of purchase. The limited availability is singled out as the strongest perceived barrier to the purchase of organic products in other studies (Torjusen et al, 2001; Lea and Worsley, 2005; Aertsens et al, 2011).

Table 1. Motives and limitation factors for consumption of organic food (literature review)

\begin{tabular}{|c|c|c|c|c|c|c|c|c|c|}
\hline & & easo & purc & & & & tation & tors & \\
\hline & 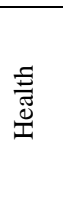 & 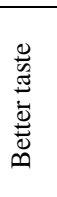 & 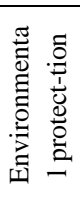 & 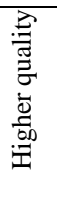 & 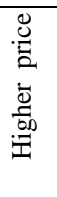 & 离 & 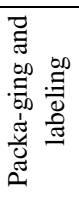 & 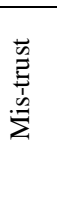 & 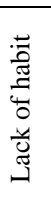 \\
\hline Vlahović and Šojić, 2016 & $\mathrm{x}$ & $\mathrm{x}$ & $\mathrm{x}$ & $\mathrm{x}$ & $\mathrm{x}$ & $\mathrm{X}$ & $\mathrm{x}$ & $\mathrm{x}$ & $\mathrm{x}$ \\
\hline Aoki, 2015 & $\mathrm{x}$ & $\mathrm{X}$ & & $\mathrm{X}$ & & & & & \\
\hline Salai et al, 2014 & $\mathrm{X}$ & $\mathrm{X}$ & & & & & & & \\
\hline Von Meyer-Höfer et al, 2014 & $\mathrm{x}$ & $\mathrm{x}$ & $\mathrm{x}$ & $\mathrm{x}$ & & & $\mathrm{x}$ & & \\
\hline Ćirić and Prodanović, 2013 & $\mathrm{x}$ & $\mathrm{X}$ & & & & & & & \\
\hline Vlahović et al, 2011 & $\mathrm{X}$ & $\mathrm{X}$ & & $\mathrm{X}$ & $\mathrm{X}$ & & $\mathrm{x}$ & & \\
\hline Aertsens et al, 2011 & $\mathrm{X}$ & $\mathrm{X}$ & $\mathrm{x}$ & $\mathrm{X}$ & $\mathrm{X}$ & $\mathrm{X}$ & & $\mathrm{X}$ & \\
\hline Rakić and Rakić, 2009 & $\mathrm{X}$ & & $\mathrm{X}$ & & $\mathrm{X}$ & $\mathrm{X}$ & & & $\mathrm{x}$ \\
\hline Renko and Bošnjak, 2009 & $\mathrm{x}$ & & $\mathrm{x}$ & & $\mathrm{X}$ & $\mathrm{X}$ & & & \\
\hline $\begin{array}{l}\text { Roitner-Schobesberger et al, } \\
2008\end{array}$ & $\mathrm{X}$ & & $\mathrm{X}$ & & & & $\mathrm{X}$ & & \\
\hline Radman, 2005 & $\mathrm{x}$ & $\mathrm{X}$ & & $\mathrm{x}$ & $\mathrm{x}$ & & $\mathrm{x}$ & & \\
\hline Lea and Worsley, 2005 & $\mathrm{X}$ & $\mathrm{X}$ & $\mathrm{x}$ & & $\mathrm{X}$ & $\mathrm{X}$ & & & \\
\hline Chinnici et al, 2002 & $\mathrm{x}$ & $\mathrm{x}$ & $\mathrm{x}$ & & & & & & \\
\hline Torjusen et al, 2001 & $X$ & $X$ & $\mathrm{X}$ & & & X & & & \\
\hline
\end{tabular}

Source: Author's own compilation

An unorganized and unstable offer has imposed the need to analyze marketing channels used for organic products, as the third research question. The selection of inadequate marketing channels, which demotivate 
consumers for shopping, require that they visit a number of stores in order to obtain all the necessary groceries, and the extended time of purchase, represent significant restrictions on the purchase and consumption of organic products. One of the research questions to which particular attention is paid is the selection of the marketing channel for the placement of organic products.

Table 2. Marketing channels used for organic products

\begin{tabular}{|c|l|}
\hline Marketing channels & \multicolumn{1}{c|}{ References } \\
\hline $\begin{array}{c}\text { Same channels as for conventional } \\
\text { products }\end{array}$ & $\begin{array}{l}\text { Vlahović and Šojić, 2016; Vehapi and Dolićanin, 2016; Da Veiga Dias et al, } \\
\text { 2016; Vlahović et al., 2011; Radman, 2005 }\end{array}$ \\
\hline \multirow{2}{*}{ Special channels for organic products } & $\begin{array}{l}\text { Vlahović and Šojić, 2016; Da Veiga Dias et al, 2016; Brčić-Stipčević et al, } \\
\text { 2011 (on saturated and growing markets) }\end{array}$ \\
\hline
\end{tabular}

Source: Author’s own compilation

Most researchers point out that organic products are delivered through the same marketing channels as conventional products (Table 2), i.e. that organic products can be found in supermarkets, hypermarkets and smaller retail stores. In addition, it should be noted that the offer of organic products is limited in these sales facilities. On domestic market, only $19 \%$ of respondents believe that the supply is satisfactory and only $2 \%$ that it is very satisfactory (Vlahović and Šojić, 2016).

Brčić-Stipčević et al. (2011) state that on saturated and growing markets specialised marketing channels, such as catering facilities, agrotourism or restaurants for organized meals, serve to popularize and increase the availability of organic products. The use of specialized and standard marketing channels for organic products could, however, contribute to reducing costs and price of these products and their promotion (Yin et al, 2010).

Finding suggest that the importance of the marketing channel is not exclusively in connecting producers and consumers of organic products, but also in contributing to consumer education. In emerging markets, consumers rely on or accept information from other market participants, in particular from retailers. They are often considered as important mediation channel to deliver information between organic food producers and consumers. Producers of organic products can even educate retailers as an effective information channel in order to convey necessary information to consumers, and to increase organic food purchase intentions (Chang and Chang, 2017).

Direct marekting channels such as on-farm sale, farm-gate, farmers market etc are present in diferent markets, but are more characteristic for less developed countries. In most of the developed countries, organic products can be bought in hipermarkets and other retail facilitates (Brčić-Stipčević et al, 2011).

The fourth research question, to which a significant attention is paid in analyzed papers, is socio-demographic characteristics of organic consumers. In practice, usually they include gender, age, income, education level and marital status, and the size of the household in which the respondents live.

The literature suggests that women are more incline to the consumption of organic products than men (Lockie et al, 2002; Lockie et al, 2004; Radman, 2005; Ćirić and Prodanović, 2013; Đokić et al, 2014; Aoki, 2015; Vehapi and Dolićanin, 2016). Although most authors have identified the existence of gender differences according to their willingness to consume organic products, only in one study it was found that there is no difference between men and women in terms of consumption of these products (Da Veiga Dias et al, 2016).

There is also significant agreement related to the link between the level of education and the consumption of organic products, in favour of respondents with higher education levels (Lockie et al, 2002; Storstad and Bjørkhaug, 2003; Radman, 2005; Roitner-Schobesberger et al, 2008; Đokić et al, 2014; Vlahović and Šojić, 2016). The only study in which such a relationship was not established was carried out in China (Yin et al, 2010). It is often emphasized that organic food consumers are married, have young children and live in larger households (Rakić and Rakić, 2009; Đokić et al, 2014; Aoki, 2015; Vehapi and Dolićanin, 2016).

A significant number of studies have confirmed the connection between higher incomes and the inclination to consume organic products (Roitner-Schobesberger et al, 2008; Yin et al, 2010; Vlahović et al, 2011; Ćirić and Prodanović, 2013; Đokić et al, 2014; Popović Vranješ et al, 2014; Vlahović and Šojić, 2016), although other authors deny the existence of such a connection (Storstad and Bjørkhaug, 2003; Lockie et al, 2004).

The most disagreement exists about the connection between the consumption of organic products and the age of consumers. Some authors (Lockie et al, 2002; Storstad and Bjørkhaug, 2003; Yin et al, 2010; Vlahović and Šojić, 2016) state that there is no link between the consumption of organic products and the age of the respondents. Others, however, state that younger consumers, up to 45 years, are more likely to buy organic products (Rakić B. and Rakić M, 2009), while a number of authors claim this for older respondents (Roitner-Schobesberger et al, 2008; Aoki, 2015; Vehapi and Dolićanin, 2016). 


\section{DISCUSSION}

Unfamiliarity with the term organic food and the inability to distinguish it from conventional products are significant limiting factors for increasing the demand for organic products. Although findings suggest that a relatively high percentage of consumers buy organic products $(61 \%$ according to Vlahović and Šojić, 2016; up to $80 \%$ according to Vehapi and Dolićanin, 2016), this can be explained with research limitations, the selection of the sample, but also, to a considerable extent, with unfamiliarity to the term "organic products". Namely, the uneducated consumers tend to equate products from the so-called domestic production and well-known producers with organic products, considering, in addition, that they buy and consume organic food, while in fact these are traditionally manufactured products. In order to increase demand and promote consumption of organic products, it is necessary to invest in promotional activities and better consumers' education. This is particularly important in the domestic market where there is a terminological confusion with the use of different terms such as "healthy", "eco" and "ecological" food. Only consumers aware of the meaning of the term "organic" product and know how to recognize it properly, can contribute to the increase of demand.

The analysis of the motives encouraging consumers to buy organic products lead to the notion that one of the highest ranked motive is their positive impact on health. The most important attributes that consumers expect from organic food can be related to "naturalness", i.e. reduced content of undesirable chemicals (such as pesticides, fertilizers and GMOs). They also consider that organic products positively affect their health and the health of their family members. In this respect, when promoting organic food, it is necessary to encourage such consumer attitudes, or use them as a motive to attract new consumers.

Sensory characteristics of organic products also represent a high-ranked motive for purchasing, but their perception is highly individual. Although consumers often associate a better taste with organic products, this purchase motive depends on the preferences of individual consumers and is not suitable for promoting the consumption of organic products.

The high price and unavailability of organic products, or relatively limited supply especially compared to conventional products, are among the most significant limiting factors of consumption. Consumers who already have a habit of using organic products are more willing to pay more for organic products. In economies with lower living standards, consumers with the lowest income will see the higher price as a significant limiting factor (Vlahović and Šojić, 2016), although according to other sources (Rakić B. and Rakić M, 2009) households with higher incomes do not show a higher probability of purchasing organic foods. Actually, some segments of consumers with lower income and in a habit of buying organic products can be more committed and loyal.

The characteristics of organic production imply the need that these products have a higher price. It can be expected that, with increase and stabilization of offer, larger number of consumers decide to purchase organic products. The proper selection of marketing channels, the expansion of supply of organic products and more acceptable packaging are factors that can induce hesitant and occasional consumers to get in the habit of consuming these products. The placement of organic products through standard marketing channels, which are used for conventional products, reducing seasonal oscillations and more attractive appearance, or packaging of organic products, are segments that need to be insisted on in order to increase their demand.

In markets with a higher standard of living, altruistic motives such as environmental protection, animal welfare or the development of local production are also significant motives for the consumption of organic products. In this respect these factors could be expected to become more important on the domestic market of organic products in the future.

Finally, key findings relate to the socio-demographic characteristics of organic products consumers. Findings suggest that women are more inclined to consume organic products, which is expected to some extent. Women continue to purchase and prepare food for the whole family, in spite of the fact that their role had been changed. Bearing in mind the consumer's view that organic food is healthier, it is expected that women will be more willing to buy products that will enable their family members a healthier and better quality diet.

Consumers of organic products are often highly educated. This can be explained by the fact that these consumers have developed a certain social responsibility, take care of environmental protection, animal welfare, and other altruistic motives, which is related to the consumption of organic products. In addition, they have developed responsibility for their own health and buy food that contribute to disease prevention, or have positive effects on the overall state of the organism, which is most often attributed to organic products.

In the same way, it is not surprising that consumers with higher incomes are more likely to consume organic products, bearing in mind that these products are more expensive. Some segment of consumers can be identified that 
have a clear need to take into account the quality of nutrition, due to poor or endangered health. These consumers would buy organic products regardless of the amount of income. They can even be more loyal customers, since they are guided by personal motives, such as health care.

\section{CONCLUSION}

Consumers believe that organic products are healthier, have no harmful ingredients and are more environmentally friendly. In this respect, the general attitude of consumers towards organic products is positive and it is necessary to develop it into real demand by appropriate activities. The starting point in these activities is to examine opinions and attitudes of consumers.

Research findings presented and analysed in this paper lead to the conclusion that consumers of organic food are mostly women living in larger families with children, with higher education and living standards. Number of factors has influence on the demand for organic food products, such as information on organic products, their organoleptic characteristics, appearance, assortment, supply, marketing channels and consumers' habits.

It is particularly important to educate consumers in order to enable them to recognize organic food and to distinguish it from conventional products. Education of retailers is significant since they are considered as main factor that can contribute to overcoming information gap related to organic food. At the same time, it is necessary to perform differentiation of organic from other types of products. Namely, the unrecognizability of the label guaranteeing the organic nature of products can mislead consumers, which is a limiting factor for increasing the consumption of these products.

\section{ACKNOWLEDGEMENT}

The paper is part of the research on the project Rural labor market and rural economy of Serbia - Diversification of income and poverty reduction, number 179028, funded by the Ministry of Education, Science and Technological Development of the Republic of Serbia.

\section{REFERENCES}

AERTSENS J, VERBEKE W, MONDELAERS K, VAN HUYLENBROECK G: Personal determinants of organic food consumption: a review. British Food Journal, 111(10)1140-1167, 2009.

AERTSENS J, MONDELAERS K, VERBEKE W, BUYSSE J, VAN HUYLENBROECK G: The influence of subjective and objective knowledge on attitude, motivations and consumption of organic food. British Food Journal, 113(11)1353-1378, 2011.

ARYAL KP, CHAUDHARY P, PANDIT S, SHARMA G: Consumers' willingness to pay for organic products: a case from Kathmandu valley. The Journal of Agriculture and Environment,10(2009)12-22, 2009.

AOKI M: Consumer loyalty towards locally certified low-input farm products. British Food Journal, 117(9)2300-2312, 2015.

BRČIĆ-STIPČEVIĆ V, PETLJAK K, GUSZAK I: Kanali distribucije i obilježja tržišta ekoloških prehrambenih proizvoda. Zbornik radova 11. znanstvenog skupa s međunarodnim sudjelovanjem „Poslovna logistika u suvremenom menadžmentu“, Osijek, Hrvatska, 20. listopada, str. 111-125, 2011.

CHANG SH, CHANG CW: Tie strength, green expertise, and interpersonal influences on the purchase of organic food in an emerging market. British Food Journal, 119(2)284-300, 2017.

CHINNICI G, D’AMICO M, PECORINO B: A multivariate statistical analysis on the consumers of organic products. British Food Journal, 104(3/4/5)187-199, 2002.

ĆIRIĆ M, PRODANOVIĆ R: Strategija pozicioniranja organskih prehrambenih proizvoda. Ekonomija, teorija i praksa, 6(3)3348, 2013.

DA VEIGA DIAS V, DA SILVA SCHUSTER M, TALAMINI E, RÉVILLION JP: Scale of consumer loyalty for organic food. British Food Journal, 118(3)697-713, 2016.

ĐOKIĆ I, ĐOKIĆ N, PAVLOVIĆ N, KOVAČ ŽNIDERŠIĆ R: Promotion of organic food in Serbia: implications from organic food consumers’ profile research. Ekonomika poljoprivrede, 61(4)837-849, 2014.

LEA E, WORSLEY T: Australians' organic food beliefs, demographics and values. British Food Journal, 107(11)855-869, 2005.

LOCKIE S, LYONS K, LAWRENCE G, MUMMERY K: Eating 'Green': Motivations Behind Organic Food Consumption in Australia. Sociologia Ruralis, 42(1)23-40, 2002.

LOCKIE S, LYONS K, LAWRENCE G, GRICE J: Choosing organics: a path analysis of factors underlying the selection of organic food among Australian consumers. Appetite, 43(2)135-146, 2004.

POPOVIĆ VRANJEŠ A, JURAKIĆ Ž, BELIĆ B, DAVIDOV I, BOŽIĆ A, OSTOJIĆ M, JEŽ G: Organic dairy production most common issues concerning health care and nutrition. Contemporary Agriculture, 63 (1-2) 153-161, 2014.

RADMAN M: Consumer consumption and perception of organic products in Croatia. British Food Journal, 107(4)263-273, 2005.

RAKIĆ B, RAKIĆ M: Upravljanje marketingom organske hrane. Ekonomika poljoprivrede, 56(3)453-468, 2009. 
RENKO S, BOŠNJAK K: Aktualno stanje i perspektive budućeg razvoja tržišta ekološke hrane u Hrvatskoj. Ekonomski pregled, 60(7-8)369-395, 2009.

ROITNER-SCHOBESBERGER B, DARNHOFER I, SOMSOOK S, VOGL CR: Consumer perceptions of organic foods in Bangkok, Thailand. Food Policy Volume 33(2)112-121, 2008.

SALAI S, SUDAREVIĆ T, ĐOKIĆ N, PUPOVAC Lj: Marketing research for choosing the promotional message content for domestic organic products. Ekonomika poljoprivrede, 61(2)501-515, 2014.

STORSTAD O, BJØRKHAUG H: Foundations of production and consumption of organic food in Norway: Common attitudes among farmers and consumers? Agriculture and Human Values 20,151-163, 2003.

TORJUSEN H, LEIBLEIN G, WANDEL M, FRANCIS CA: Food system orientation and quality perception among consumers and producers of organic food in Hedmark County, Norway. Food quality and preference, 12(2001)207-216, 2001.

VEHAPI S, DOLIĆANIN E: Consumers behavior on organic food: evidence from the Republic of Serbia. Ekonomika poljoprivrede, 63(3)871-889, 2016.

VLAHOVIĆ B, ŠOJIĆ S: Istraživanje stavova potrošača o organskim poljoprivredno-prehrambenim proizvodima i njihovim brendovima. Agroekonomika, 45(70)33-46, 2016.

VLAHOVIĆ B, RADOJEVIĆ V, ŽIVANIĆ I: Istraživanje stavova potrošača o potrošnji organske hrane u Srbiji. Ekonomika poljoprivrede, 58(3)443-456, 2011.

VON MEYER-HÖFER M, NITZKO S, SPILLER A: Is there an expectation gap? Consumers' expectations towards organic. British Food Journal, 117(5)1527-1546, 2015.

YIN S, WU L, DU L, CHEN M: Consumers' purchase intention of organic food in China. Journal of the Science of Food and Agriculture, 90(8)1361-1367, 2010.

ZANOLI R and NASPETTI S: Values and Ethics in Organic Food Consumption. $3^{\text {rd }}$ EurSafe Congress Food Safety, Food Quality and Food Ethics, Florence, Italy, 3-5 October 2001.

\title{
SPECIFIČNOSTI TRAŽNJE NA TRŽIŠTIMA ORGANSKE HRANE
}

\author{
Marija NIKOLIĆ ${ }^{2}$
}

Izvod: Tržište organske hrane u Srbiji karakteriše nedovoljno razvijena ponuda i ograničena tražnja. Tražnja za organski proizvedenom hranom ima određenih specifičnosti. U radu se analiziraju rezultati sprovedenih istraživanja domaćih i stranih autora sa ciljem da se identifikuju ključne karakteristike, kao i da se izvrši sistematizacija faktora koji opredeljuju tražnju i potrošnju organskih proizvoda na našem i inostranim tržištima. Cilj istraživanja je izrada demografskog profila organskog potrošača, odnosno stvaranje slike o „tipičnom“ potrošaču organske hrane.

Većina autora se slaže da postoji pozitivna korelacija između nivoa obrazovanja i potrošnje organskih proizvoda. Istraživanja sprovedena u Srbiji ukazuju da briga za zdravlje predstavlja jedan od važnijih faktora kupovine organski proizvedenih proizvoda, dok su inostrani kupci, pored toga, motivisani i brigom za životnu sredinu, dobrobiti životinja, ali i težnjom da se hrane „lokalnom“ hranom. Kod obe grupe potrošača senzorna svojstva proizvoda predstavljaju jedan od ključnih faktora potrošnje. Cena je jedan od važnijih faktora koji opredeljuju kupovinu ovih proizvoda. Značajna pažnja se posvećuje i kanalima marketinga. Kako se kao osnovna karakteristika poslovanja domaćih organskih proizvođača ističe nerazvijenost i neprilagođenost zahtevima potrošača, upoznavanje sa osnovnim karakteristikama kupaca organskih prehrambenih proizvoda predstavlja polaznu osnovu za izradu adekvatne marketing koncepcije uzgajivača, ali i prerađivača i maloprodaje ove grupe proizvoda.

Ključne reči: tražnja, karakteristike, potrošači, tržište organske hrane

\section{ZAHVALNICA}

Rad predstavlja deo istraživanja na projektu Ruralno tržište rada i ruralna ekonomija Srbije - Diverzifikacija dohotka i smanjenje siromaštva, broj 179028, koji finansira Ministarstvo prosvete, nauke i tehnološkog razvoja Republike Srbije.

\section{Received / Primljen: 15.07.2017. \\ Accepted / Prihvaćen: 18.12.2017.}

\footnotetext{
2 Dr Marija Nikolić, docent, Poljoprivredni fakultet Univerziteta u Beogradu, Nemanjina 6, Srbija, tel: 011/4413-493, E-mail: mnikolic@agrif.bg.ac.rs
} 